\title{
ペルオキシソームはどのようにしてできるのか? 酻母ペオキシンとペルオキシソーム膜タンパク質
}

\section{阪井 康能*}

長い間, 不毛の化石オルガネラと考えられてきたペルオキシ ソーム. 今, 酵母をモデル生物として, ペルオキシソームの 形成を司るタンパク質因子ペルオキシンと光の遺伝子が続々 と神秘のベールを脱ぎ始め, 細胞生物学のシンデレラとして 再登場しつつある. 金コロイドを含む巨大タンパク質です ら，光のまま通してしまうユニークなタンパク質膜透過機構 の存在が明らかとなり, ヒト・ペルオキシン遺伝子もクローニ ングされ, 遺伝病の特効薬としても期待されている.オルガ ネラの形成に関わるペルオキシンとペルオキシソーム膜タン パク質機能の最新像を概説する。

近年, 分子細胞生物学の発展には目覚ましいものがあ る. 酵母細胞は遺伝学・分子生物学的手法が使える単細 胞真核生物であり, その多細胞生物のモデル系として果 たしている役割は大きい。それは，酵母と多細胞高等生 物との間で, 分子レベルにおける構造・機能面での共通 項が明らかにされるにつれ, 酵母モデル系の利用価值が ますます大きくなってきたからである.

細胞内オルガネラの一つであるペルオキシソームの形 成に関する研究では, Pichia pastoris, Candida boidinii

\footnotetext{
Molecular Mechanism of Peroxisome Assembly ${ }^{*}$ Yasuyoshi SAKAI, 京都大学大学院農学研究科応用生命科学専 攻
}

表 1 ロペルオキシンと光の遺伝子

遺伝子 ペルオキシンの特徵

PEX1 AAA ファミリーに属する ATPase, $117 \sim 127 \mathrm{kDa}$

$P E X 2 \quad \mathrm{C}_{3} \mathrm{HC}_{4} \quad \mathrm{Zn}$-結合型ペルオキシソーム膜タンパク質, 35 $\sim 52 \mathrm{kDa}$, Zellweger 症候群 (CG 10)

$P E X 3$ ペルオキシソーム膜タンパク質, $51 \sim 52 \mathrm{kDa}$

$P E X 4$ ユビキチン結合酵素

PEX5 PTS1 レセプター, 64〜69kDa, 7 8 回の TPR 繰り返し 構造, Zellweger 症候群(CG 2)

PEX6 AAA ファミリーに属する ATPase, 112〜127 KDa, Zellweger 症候群 (CG 4)

PEX7 PTS2 レセプター, 37〜42 kDa, 6 回の WD40 繰り返し構 造, 斑状軟骨形成不全症 II 型(RCDP/CG 11)

$P E X 8 \quad \mathrm{PTS} 1$ をもつペルオキシソームタンパク質, $71 \sim 81 \mathrm{KDa}$

$P E X 9$ ペルオキシソーム膜タンパク質, $42 \mathrm{kDa}$

$P E X 10 \quad \mathrm{C}_{3} \mathrm{HC}_{4} \quad \mathrm{Zn}$-結合型ペルオキシソーム膜タンパク質, 34 $\sim 48 \mathrm{kDa}$

$P E X 11$ ペルオキシソームの分裂に関与する膜タンパク質, 27 $\sim 32 \mathrm{kDa}$

$P E X 12 \quad \mathrm{C}_{3} \mathrm{HC}_{4} \quad \mathrm{Zn}$-結合型ペルオキシソーム膜タンパク質, 40 $\sim 48 \mathrm{kDa}$, Zellweger 症候群 (CG 3)

PEX13 Pex5p に結合する SH3 ドメインをもつタンパク質, 40 $\sim 43 \mathrm{kDa}$

PEX14 Pex5p, Pex7p, Pex13p に結合するペルオキシソーム膜夕 ンパク質, $38 \sim 39 \mathrm{kDa}$

特に必要な場合, 遺伝子名の前に, 遺伝子が由来する生物種の学名 の種族名より 1 字ずつとって,イタリックで加える(例：Saccharomyces cerevisiae の場合はScPEX1, ヒト Homo sapiens の場合 は HsPEX2 など). また, 特に酵母の場合, その一般表記法に従っ て，遺伝子産物であるタンパク質については，たとえば ScPEX1 の遺伝子産物は $S c P e x 1 p$ と表現する. $\mathrm{C}_{3} \mathrm{HC}_{4}: 3$ 残基のシステイ ン, ヒスチジン, 4 残基のシステイン. 
などのメタノール資化性酵母が, 出芽酵母 Saccharomyces cerevisiae と並んでモデル生物として用いられて いる．特に酵母遺伝子をべースにしたデータベース検索 により，ペルオキシソーム遺伝病遺伝子のクローニング が行なわれたことは，このような研究における酵母実験 系の妥当性を強調することとなった ${ }^{(1)}$. 以上のようなこ とと相まって，ペルオキシソーム形成や維持に関わる夕 ンパク質因子の命名法を全生物について統一すること になり，タンパク質因子をペルオキシン(peroxine)，コ ードしている遺伝子を $P E X$ 遺伝子と呼ぶこととなった (表 1) ${ }^{(2)}$.

本稿では，ペルオキシソーム形成・分裂の分子メカニ ズムについて，主に酵母実験系より得られたこれまでの 成果を概括し，筆者らが行なったメタノール資化性酵母 のペルオキシソーム膜タンパク質 (peroxisome membrane protein ; Pmp）の機能との関連性について考察 したい.

\section{酵母ペルオキシソームの代謝系と誘導炭素源}

ペルオキシソームは, 酵母から高等動植物に普遍的に 存在する単膜オルガネラである。オルガネラ内には過酸 化水素を発生するオキシダーゼと過酸化水素を分解する カタラーゼが局在しており, 主に脂肪酸 $\beta$-酸化などの酸 化系代謝を司っている.

S. cerevisiae ではオレイン酸生育時にペルオキシソ 一ムが形成され, この際, オルガネラ内には脂肪酸 $\beta$-酸 化に必要な酵素が誘導される。一方，メ夕ノール資化性 酵母をメタノールで生育させると，アルコールオキシダ 一ゼ(AOD), ジヒドロキシアセトンシンターゼ(DHAS) およびカタラーゼ (CTA) がマトリクスタンパク質とし て誘導され，ペルオキシソームはその細胞内に占める 体積の割合が $80 \%$ 近くになるまでに大きく発達する. メタノール資化性酵母であるP. pastoris おょび C. boidinii では，このようなメタノール代謝系だけでなく， $\beta$-酸化代謝系も併せてもっているため, オレイン酸を単 一の炭素源としても生育することができる.さらに $C$. boidiniii は, D-アラニンも炭素源として生育し, D-アミ ノ酸オキシダーゼをもつペルオキシソームを誘導する. ペルオキシソーム形成を行なうことができない pex 変 異株は, P. pastoris では 2 つ炭素源に, C. boidinii で は 3 つのペルオキシソーム誘導炭素源に生育することが できない変異株の中から分離された ${ }^{(3,4)}$.ペルオキシソー ムを誘導し，かつ代謝系としてはあまり関係のない複数 の炭素源に生育できるというメタノール資化性酵母の生

育特性は, 代謝系変異株を排除して pex 突然変異株の取 得のためのスクリーニング効率を高めることとなった。

\section{ターゲティングシグナルとタンパク輸送}

1. ターゲティングシグナル $(\mathrm{PTS} 1, \mathrm{PTS} 2, \mathrm{mPTS})^{(5 \sim 7)}$ ペルオキシソームへ輸送されるタンパクは, ミトコン ドリアなど他のオルガネラと同様に, 遊離のリボソーム 上で合成され，そのタンパク質配列中にあるペルオキシ ソームターゲティングシグナル (peroxisome targeting signal ; PTS)の働きにより,ペルオキシソームへ輸送さ れる。ペルオキシソームに局在するマトリクスタンパク 質のほとんどは, PTS 1 と呼ばれるカルボキシル末端に ある 3 つのアミノ酸配列 SKL を基本モチーフとする配 列をもっている (図 1). PTS 2 は，N 末端付近に存在す

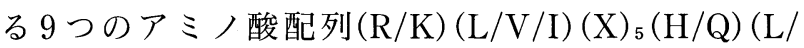
A)であり，チオラーゼ，アミンオキシダーゼなどのいく つかのタンパク質で知られている. 膜タンパク質のソー ティングシグナルである mPTS に関しては, 数種類の タンパク質で明らかにされつつあるが, 最も研究の進ん でいるのは, 後でその機能について考察する C. boidinii Pmp47である(6).その mPTS は, ペルオキシソームマ トリクス内にループ構造をとっている 20 アミノ酸に限 定されている. 同様に, PpPex3pでは, $\mathrm{N}$ 末端 40 まで のアミノ酸配列内に mPTS がある.いずれの mPTS に

マトリクスタンパク質

-PTS1 C末端 トリペプチド

$\mathrm{H}_{2} \mathrm{~N}=\frac{\mathrm{SKL}}{\mathrm{ARM}} \mathrm{COOH}$

-PTS2Ｎ末端または内部ノナペプチド

例）ルシフェラーゼ ほとんどのマトリクス 酵素

$\mathrm{H}_{2} \mathrm{~N} \underset{\mathrm{XXRLQX5HL}}{\longrightarrow} \mathrm{COOH}$ 例）チオラーゼ KV QA

膜タンパク質

- mPTS マトリクスにある塩基性アミノ酸の $\mathrm{COOH}$ 多い配列

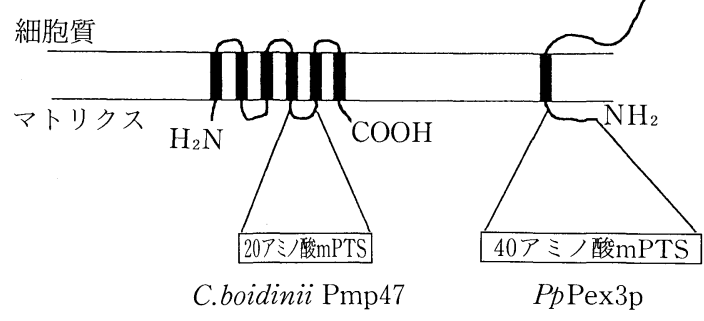

図 1 ロペルオキシソームターゲティングシグナル (PTS) 
おいても，モチーフははっきりしないが，いくつかの塩 基性アミノ酸が連なったペプチドの部分構造（ストレッ チ）があり, mPTS は膜貫通領域でなくオルガネラ・マ トリクス内にある. mPTS は輸送シグナルとして機能す るが, 疎水性の高い膜貫通領域により捕捉される輸送停 止機構によって起こるのではないかと考えられており, これは翻訳後にペルオキシソームへ輸送されるというモ デルとも矛盾しない.

以上の PTS は，いずれもペルオキシソームへのタン パク質輸送に必要かつ十分な配列である。すなわち, PTS をペルオキシソームタンパク質から除くと,ペルオ キシソームへ輸送されず細胞質に留まり(必要性), また レポータータンパク質に PTSを付加するとレポーター タンパク質はペルオキシソームへ輸送される (十分性).

ごく最近, 小胞体 (ER)を経てペルオキシソームへ輸送 される膜タンパク質である $S c P \operatorname{Pex} 15 \mathrm{p}$ が明らかにされ た ${ }^{(7)}$. ScPex15p の過剩発現は ER 膜の異常増殖を誘導 する. 384 アミノ酸のうち, C 末端から 55 アミノ酸を除 去すると, ScPex $15 \mathrm{p}$ は $\mathrm{ER}$ へ運ばれ, 12 アミノ酸を残 しておくとペルオキシソームへ輸送される. ER を介し て輸送される Pmp が発見されたことは, ペルオキシソ 一ム膜の由来や分泌系小胞輸送との関連を考察する上で 興味深い.

\section{PTS1, PTS2 レセプター(Pex5p, Pex7p)およびこれ らと相互作用する Pex13p, Pex14p}

$P E X$ 遺伝子がクローニングされ始めた当初から, PTS を直接認識するPTSレセプターの存在は予想さ れていた。酵母 pex 突然変異株の解析が進むにつれ，そ の性質が明らかになっていった。すなわち，ほとんどの pex 変異株においては, PTS1 酵素および PTS2 酵素の 両者とも細胞質に局在してペルオキシソームに輸送され ていないのに対し, pex5 変異株では, PTS1 酵素のみが ペルオキシソームへ輸送されず PTS2 酵素の輸送は正 常であり, これとは逆に pex 7 変異株では, PTS1 酵素 の輸送は正常で PTS2 酵素のみが輸送されていない(3).

P. pastoris pex5 突然変異を相補する（変異した性 質が回復する）ことによりPpPEX5 遺伝子がクローニ ング・構造決定され, その配列をもとにデータベース検 索することにより, ヒトPEX5 遺伝子もクローニングさ れた ${ }^{(8)}$. PEX5 遺伝子はS. cerevisiae, C. boidinii など 数種の酵母からもクローニングされている.いずれも Pex5p は 64〜 69 kDa のタンパク質で, TPR モチーフ構 造を 7〜8 回もつ. Pex5p の PTS1 ペプチドに対する結 合活性も生化学的に確認され, PTS1 レセプターである

\section{用語解説}

TPR (tetratricopeptide repeat)
およびWD40 モチーフ配列 どちらのモチー フも機能は特定 されていない が，アミノ酸配列の類似性に基づいて規定されている モチーフ構造で，重要な機能をもつ様々なタンパク質 によってファミリーを形成している. TPR モチーフ は34アミノ酸の繰り返しからなり, snap helix 構造 をとっている.このファミリーは DNA に結合するも のが多いが，PTS1レセプターである Pex5p と同様 に，ミトコンドリアタンパク質のレセプターである Mas70p も TPR モチーフをもっている. 一方, WD40 モチーフ配列は，Trp-Asp 配列が特徵的な 40 アミノ 酸からなるモチーフ構造で, $\mathrm{A}$ および $\mathrm{B}$ の保存された 配列部分がある.Pas7p では 5 回の B 構造の繰り返し があるが, $\mathrm{A}$ 構造はない. $\mathrm{G}$ タンパク質の $\beta$ サブュニ ットなどにみられ, シグナル伝達, スプライシング, 転写制御など，多くの生物機能に関与したタンパク質 が知られている.TPR モチーフ構造をもつタンパク質 とWD40 モチーフ構造をもつタンパク質が直接相互 作用している例も知られているが, Pex5p と Pex7pの 相互作用は Pex14p を介して行なわれており，直接の 相互作用はない.

ことが証明された ${ }^{(8)}$. TPR モチーフ繰り返し部分に PTS1 結合活性がある.Pex5p の局在性については生物 種によって, 細胞質, ペルオキシソーム膜, マトリクス とまちまちであるが, これは Pex5p が細胞質とマトリク ス間を行き来している (shuttling) ためと考えられてい る ${ }^{(5)}$. ヒトPEX5 は Zellweger 症候群 (CG 2)の病因遺 伝子であることもわかった ${ }^{(8)}$.

Pex5p と相互作用するペルオキシソーム膜タンパク 質として, Pex13p が同定された ${ }^{(9 \sim 11)}$. Pex5p のペルオ キシソーム膜におけるレセプターであると考えられてい る(図 2).

PTS2 レセプターである Pex7pも, PTS1 レセプター と同じ手法により，酵母，ヒト，マウスからクローニング された。Pex7p は WD 40 繰り返し構造をもつタンパク 質であり, two-hybrid システムにより PTS2 配列との 特異的結合が示された ${ }^{(12,13)}$. ヒト PEX7 は, Rhizomelic chondrodysplasia punctata (RCDP ; 斑状軟骨形成不 全症II型）の病因遺伝子であった ${ }^{(1)} . S c P e x 7 \mathrm{p}$ の局在性 については, マトリクスあるいは細胞質のどちらにある かで 2 つグループの論争点となっている ${ }^{(5,12)}$.

ヒト pex 5 欠損培養細胞株では, 酵母 pex 5 変異株と異 なり, PTS1, PTS2 両経路が欠損していた.さらに, ヒ トPex5pには同じ遺伝子によってコードされ, スプライ 


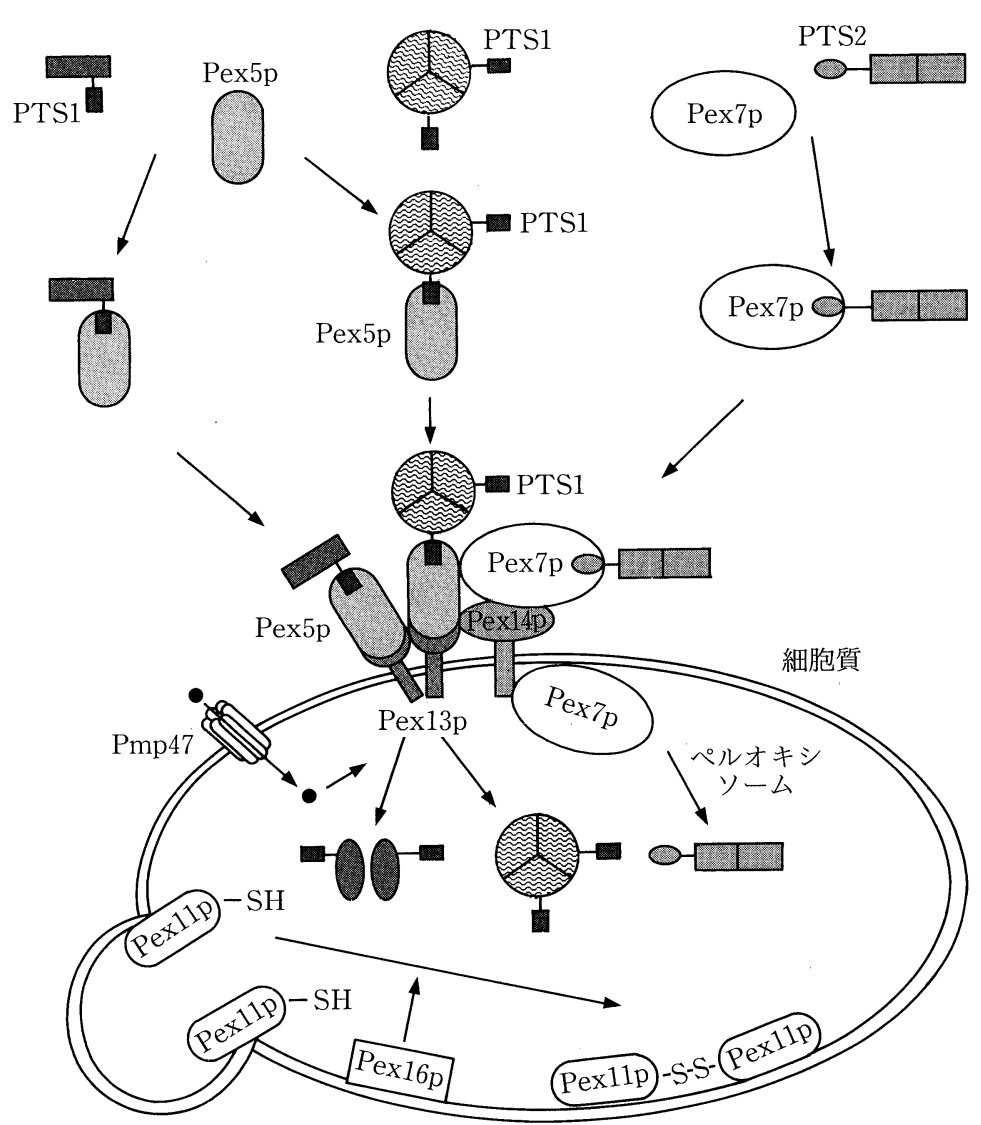

図 2 ロ酵母ペルオキシソームへのタンパク質輸送（PTS1, PTS2 経路）と各ペルオキシンおよび Pmp47 の作用を示した概念 図 (本文参照)

PTS1 またはPTS2 をもつマトリクスタンパク質は，それぞれのレセプターである Pex5p または Pex7p に結合してペルオキシソームへ輸 送される. Pex5p はペルオキシソーム膜にある Pex13p に結合する. Pex14p は Pex 5p, Pex7p の両者と相互作用している. PTSをもたな いタンパク質でも, PTS をもつタンパク質とオリゴマーを形成してペルオキシソームへ輸送されうる. 一方, ペルオキシソームのタンパク 質輸送には, Pmp47 の輸送する低分子化合物を要求するものとそうでないものがある. ペルオキシソーム内へ輸送されてからフォールディ ングされるタンパク質もあるのかもしれない,一方, Pex11p はモノマーとしてペルオキシソームの分裂を促進し, ペルオキシソームの成熟 に伴いダイマーとなり不活化する. Pex16p はこの過程を活性化して分裂を調節しているのかもしれない.

シングの段階で 2 種類の長さの異なる mRNA によりコ ードされる long form (1-Pex5p) と short form ( $\mathrm{s}^{-}$ Pex5p)がある. 興味深いことに, 1-Pex5p はPTS1, PTS2 両経路を相補できるのに対し, s-Pex5p はPTS1 輸送経路を相補できるが，PTS2 経路を相補できない。 以上のことから, PTS1 経路と PTS2 経路の間の相互作 用が予測されていた ${ }^{(5)}$. 最近, 酵母で Pex5p および Pex7p の両者に相互作用する因子として Pex14p が同 定された ${ }^{(14)}$. 他の $P E X$ 遺伝子とは異なり, PEX14の 過㮃発現はペルオキシソーム欠損の表現系を示し, 細胞

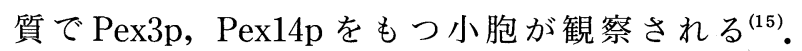
Pex14p の量がペルオキシソームの形成に重要な意味を もっているのかもしれない.

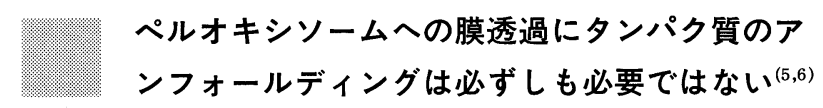

$\mathrm{ER}$ やミトコンドリアへのタンパク質輸送は, 膜を透 過し始めてからタンパク質が正しくフォールディングさ れて活性型になる。そのために Hsp70/Hsp60 などのシ ヤペロン分子が必要である.このような背景から, ペル オキシソーム内にあるシャペロン分子が検索されてき た。

しかし，(1) PTS をもたないサブユニットタンパク質 でも，PTSをもつ他のサブュニットとオリゴマーとな った後, ペルオキシソームへのタンパク質輸送が起こ る ${ }^{(6)}$, (2) 化学架橋剤, S-S 結合により安定化され, $9 \mathrm{~nm}$ の金コロイド粒子をもつフォールディングされた巨大な タンパク質分子でも，アンフォールディングされずその 
ままペルオキシソームへ輸送される(5)，という驚くべき 実験結果が報告された。これは，ペルオキシソームへの タンパク質輸送には必ずしもアンフォールディングは必 要でなく, タンパク質がオリゴマー化してからでもぺル オキシソームへ輸送されることを示唆している (図 2). ペルオキシソーム膜でのタンパク質の膜透過は, 他の才 ルガネラでの場合とは大きく異なるまったく新しい夕イ プの機構が関与すると予想される。

\section{C. boidinii ペルオキシソーム膜タンパク質と 逆遺伝学を利用した機能解析}

\section{1. ペルオキシソーム膜タンパク質と発現制御 ${ }^{(16)}$}

現在まで PEX 遺伝子のクローニングは，主に酵母， $\mathrm{CHO}$ 培養細胞における pex 変異株の相補性を利用して 行なわれている。これとは異なったアプローチにより, Goodman らと筆者らは, 新たな Pmp がペルオキシソ 一ム形成に関与していることを明らかにすることができ た。

ペルオキシソーム膜が，タンパク質輸送に関する重要 な機能を担っていることは想像に難くない。が，酵母 Pmp に関する研究は, Goodman らにより C. boidinii を用いて始められるまで皆無だった。C. boidinii は, ぺ ルオキシソームの生化学的解析には優れたモデルであ る.その理由の一つは, 高純度の Pmp を精製できるこ とである. 図 3 は, メタノール培養菌体から Pmp を調 製した際の結果を示したものである。マトリクスタンパ ク質である AOD, DHAS の他に, SDS-ポリアクリルア ミドゲル電気泳動(PAGE) 上にはそれぞれその分子量 (kDa)に応じて, Pmp47, CbPex11p (C. boidinii では Pmp30, S. cerevisiae では Pmp27 と命名されていた), Pmp20が見いだされた。

次に，これらの Pmp を以下のような基準によって分 類した。C. boidinii は先にも述べたように，代謝的にま ったく異なる 3 つのペルオキシソームを誘導する炭素 源，すなわちメタノール，オレイン酸，D-アラニンを利 用でき，各炭素源で誘導したときのペルオキシソームの タンパク質構成は異なっている。すなわち，ペルオキシ ソームの構成タンパク質には，AODのようにメタノー ル生育時にのみ見いだされる代謝特異的なものと，代謝 には依存せず構成的に見いだされるものとに分類でき る。ペルオキシソームの形成や維持のように，オルガネ ラの基本的な機能に関わる分子は後者に属するものであ ることが予想された。このような基準によって Pmpの 分類をしてみると, Pmp20 はメ夕ノール培養時にのみ 見いだされるが，オレイン酸，D-アラニン培養時にはみ

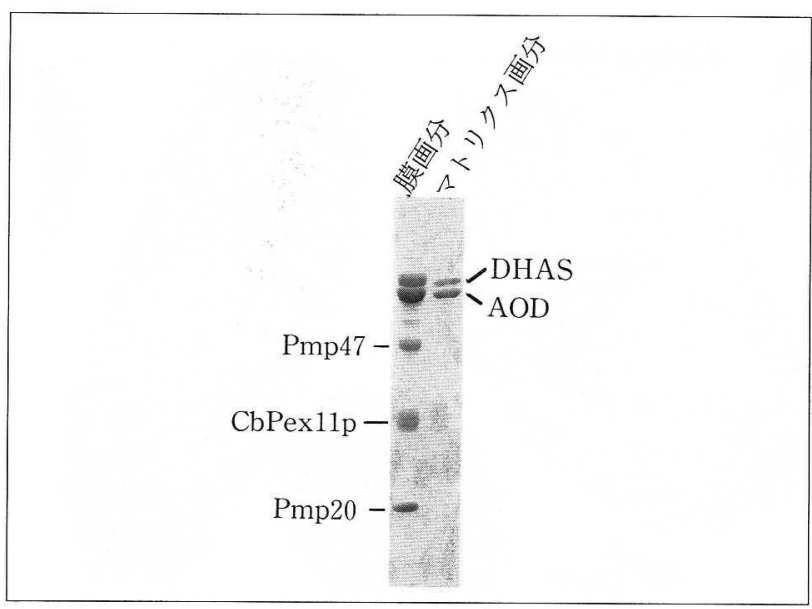

図 3 - C. boidinii メタノール生育菌体より精製したペルオ キシソーム膜タンパク質

ペルオキシソーム精製画分を $30 \mathrm{~mm}$ Tris- $\mathrm{HCl}, \mathrm{pH} 8.0$ の温和な 条件で破砕した後, 浮遊密度勾配超遠心により膜画分とマトリクス 画分に分け, SDS-ポリアクリルアミドゲル電気泳動にかけて, ク ーマシー染色を行なった。メタノールで誘導したペルオキシソーム の主なタンパク質は AOD と DHAS であり, CTA はマイナータ ンパク質で，バンドとしては認められない.膜画分にはこれらの $\mathrm{AOD}$ および DHAS とともに, 3 種類の Pmp が観察される.ちな みに,こうして得られた膜画分を $100 \mathrm{~mm}$ 重炭酸ソーダで洗浄する と, AOD は解離するが，他の Pmp と DHAS は膜画分に残る。

られない。それに対して, Pmp47および $C b P \operatorname{Pex} 11 \mathrm{p}$ （Pmp30）は上の 3 つの炭素源いずれで培養したときに もペルオキシソームに見いだされた。したがって, Pmp20 はメタノールに代謝特異的な分子で，Pmp47 と CbPex11p はより基本的な機能をもった分子であること が予測された(16).

ちょうどそのようなことが明らかになってきた頃，筆 者らは C. boidinii の分子育種系を構築し, 遺伝子破壞 や異種遺伝子を発現させることに成功した ${ }^{(17)}$.そこでま ず，これらのP P mp 遺伝子を宿主株である S2 株より再ク ローニングし, 遺伝子破壞を行なって, 遺伝子破壊株に おける生育特性をべースに機能を探ろうとする “逆遺伝 学 (reversed genetics)”によるアプローチをとること にした。

\section{2. ペルオキシソームの分裂を促進する Pex11p}

Pex11p はペルオキシンの中で, 唯一タンパク質の部 分アミノ酸配列をもとに遺伝子がクローニングされ, 遺 伝子破壞株が作製されるという過程を経た，いわゆる逆 遺伝学によってその機能が解析されたものである.

C. boidinii の PEX11 遺伝子破壞株である pex11ム株 では，オレイン酸およびメタノールを炭素源としたとき に生育阻害が認められたが, 特にメタノールのときに顕 著な生育阻害が認められた ${ }^{(18)}$ 。他の pex 変異株とは異 

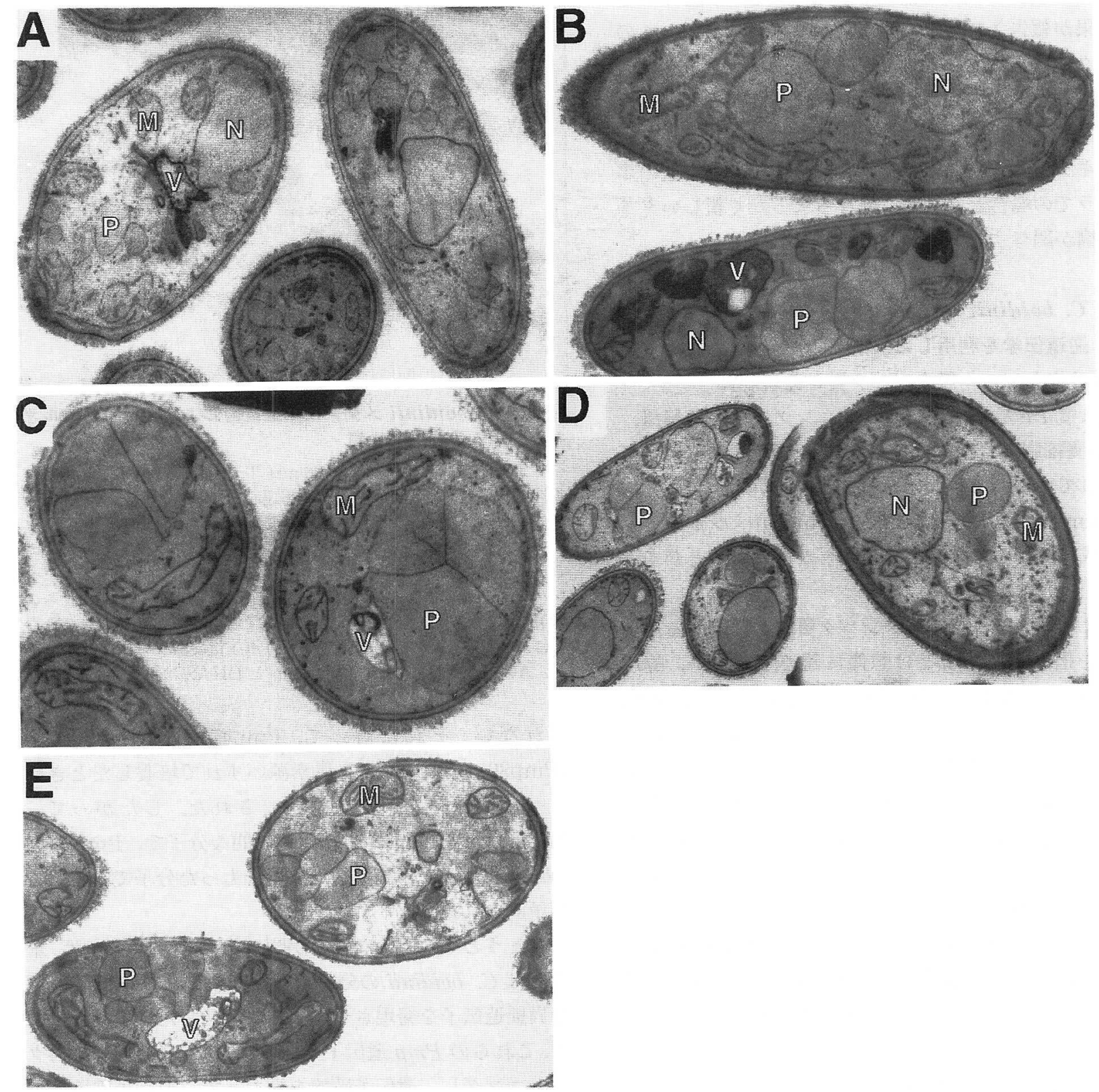

図 4 - C. boidinii pex114 株（遺伝子破壞株）と野生株の電顕写真 (本文参照) ${ }^{(18)}$

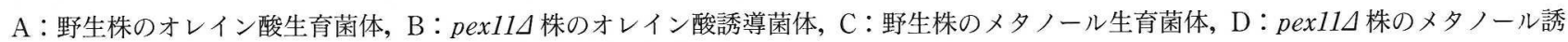
導菌体, $\mathrm{E} ： \operatorname{pex11\Delta }$ 株で $\mathrm{ScPEX11}$ を過剩発現させた。

野生株では，用いた炭素源によって特徵的な形態が観察され，分裂中のペルオキシソームなどがみられる(A および C)。一方，pex11」株 では巨大なペルオキシソームが細胞内に 1 2 個観察される(B および D).一方, PEX11 過剩発現株ではペルオキシソームの分裂が促進さ れて，小型化したペルオキシソームが多数観察される $(\mathrm{E})$.

$\mathrm{P}$ : ペルオキシソーム, $\mathrm{M}$ ：ミトコンドリア, $\mathrm{N} ：$ 核, $\mathrm{V}$ : 液胞

なって, ペルオキシソームへのタンパク質輸送に異常は みられない。しかし，ペルオキシソームの形態には著し い変化が認められた。オレイン酸で培養した $C$. boidinii 野生株では，メ夕ノール培養菌体に比較して小 型のペルオキシソームが，細胞当たり平均 5〜10 個程度 観察される(図 4-A)。それに比較して, pex11」株では 大きな球形のペルオキシソームが細胞当たり $1 \sim 2$ 個し
かみられないのが特徵である(図 4-B)。メタノール培湌 菌体においても，野生株に比べて(図 4-C), pex11」株で は分裂中のペルオキシソームはほとんどみられず, 球形 のペルオキシソームが細胞当たり 1〜2 個見いだされた (図 4-D)。このようなペルオキシソームの形態は S. cer evisiae pex11ム株でも同様であった ${ }^{(19,20)}$.

C. boidinii およびS. cerevisiaeにおいては，それぞ 
れの pex11 変異を異種のPEX11 遺伝子で，相互に相 補することができた ${ }^{(18)}$ 。これは $P E X$ 遺伝子の中で，異 種間の相補性が確認された初めての例である。この場合 の相補性とは, 生育の回復とペルオキシソームの小型化 を意味する.図 4-E には ScPEX11 をCbpex11ム株で過 剩発現させたときのものを示している．このようにメタ ノール培養菌体では, 本来もっと大きなペルオキシソー ムが存在するが(図 4-C), 過剩発現株ではさらにペルオ キシソームが分裂して小型化しているのがわかる（この ような過剩発現株でも生育阻害は回復している).ここで 重要なのは, S. cerevisiae はメタノールの代謝系をもっ ていないにもかかわらず，ScPEX11 がCbpex110株の メタノールでの生育阻害を回復できたことである。つま り Pex11p は代謝とは関係なく, 基本的なペルオキシソ ーム機能に関係していることが示された。

さて Pex11p の生産量とペルオキシソームの形態の関 係は何を意味しているのだろうか？ 筆者らは Pex11p をペルオキシソームの分裂を促進する分子として捉えて いる.たとえば, 免疫電顕による観察では Pex11p はペル オキシソームが分裂する際にみられるくびれ（neck）部 分に観察されている(19). またPex11p は，そのCys 残基 による S-S 結合を介してホモダイマーとしても存在し ていることがわかった。モノマーは，未熟なペルオキシ ソーム（密度勾配超遠心で軽い画分）に多く存在し，逆 にホモダイマーは成熟した（重たい）画分のペルオキシ ソームに多かった。さらにホモダイマー形成に必要な Cys 残基を Ala に遺伝子工学的に変換すると, Pex11p の過剩発現株と似て軽くて未熟なペルオキシソームが多 数できた ${ }^{(21)}$. Pex11p はペルオキシソームが成熟するま での間はモノマーとしてオルガネラの分裂に寄与し，ペ ルオキシソームが成熟してしまうとホモダイマー化して 不活性化しているのかもしれない.

最近，このような Pex11p の機能の調節に関与して いる可能性のある分子として, Pex16p が明らかにな った ${ }^{(22)}$. Pex16p は Pex11p の逆の表現系を示す.すなわ ち, Pex16p 過剒生産は巨大なペルオキシソームの形成 をひき起こす. 今後, Pex11p との相互作用の解明が興味 深い. Pex16p は Pex11pのホモダイマー化を促進して いるのかもしれない.

\section{Pmp47 のトランスポーターとしての機能とペルオキ シソームへのタンパク質輸送の生化学的多様性 ${ }^{(23)}$}

Pmp47 の推定アミノ酸配列が発表された後, この夕 ンパク質がミトコンドリアATP/ADP 交換輸送体な ぞ，低分子化合物のトランスポーターと高い類似性をも
つ分子であることが明らかになった。

PMP47 遺伝子を破壊した $p m p 47 \Delta$ 株では，メ夕ノー ルにおける生育は完全に抑制され，オレイン酸でもかな り生育阻害がかかっていた。電顕観察を行なうと, ペル オキシソームは存在していたが, メタノール培養菌体, オレイン酸培養菌体ともに, 細胞質中に電子密度の高い タンパク質の凝集体と考えられる構造が見いだされた。

メタノール培養時のマトリクス酵素は AOD, DHAS, CTAの 3 種類であり, そのタンパク質構成は単純であ る.そこでメタノール誘導菌体を用いて, PMP47 遺伝子 の破壊と酵素活性の関連から解析を始めることにした。 すると pmp474株では, AOD, CTA 活性は通常レベル で認められたものの, DHAS 活性はまったく消失してい た。しかも DHAS タンパク質はフォールディングした 形では細胞内にはまったく存在しておらず，凝集体とな って存在していることがわかった，次に，このような凝 集体となったDHAS タンパク質の細胞内局在性を検討 した. 免疫電顕, ショ糖密度勾配分画による結果から, AOD，CTA はペルオキシソームへ正常に輸送されてい たが, DHAS はフォールディングされていない凝集体と して細胞質にとどまっていることが明らかになった。こ のように, Pmp47 が DHAS のペルオキシソームへの夕 ンパク質輸送とフォールディング, 活性発現に深く関与 していた。

トランスポーターは膜で仕切られている環境ではじめ て機能する分子である。では，もしそのような仕切りを 取り除いてやれば, DHAS は Pmp47 がなくても活性発 現できるようになるのだろうか？ それとも，Pmp47 はトランスポーターとしての機能以外にシャペロン機能 ももっていて DHAS のフォールディングに直接関与し ており, DHAS の活性発現には必ず必要な分子なのであ ろうか？この疑問に答えるため, PMP47 遺伝子破壊 をもともとペルオキシソームを形成できない pex 変異 株で行なった.このような $p e x / p m p 47 \Delta 二$ 二重変異株では DHAS 活性は正常レベルで認められ, AOD, DHAS 夕 ンパク質は細胞質に存在した。 以上の結果から, Pmp47 分子は DHAS の活性発現にとって必ずしも必要でない ことがわかった。

AOD，DHAS は，ともにPTS1 経路により輸送され るタンパク質である.しかし, DHAS の輸送には, 細胞 質からペルオキシソーム内へ Pmp47 によって輸送され る低分子化合物を要求するが，AOD はそれを要求しな い. 筆者らの結果は, PTS 以外にペルオキシソームへの タンパク質輸送に打ける生化学的要求性の多様性を初め て示唆したものである. 
では，なぜ $p m p 47 \Delta$ 株では，フォールディングできな かった DHAS 凝集体が細胞質にみられたのだろうか？ さらに，この表現型は pex 变異によって打ち消されて （抑圧されて）いた。 pex/pmp47A二重変異株では DHAS が正しくフォールディングされており, DHAS はPmp47 がなく, 必ずしも膜を透過しなくても, 細胞質 において活性型になり得る。これらの結果からは, DHAS がフォールディングされてからペルオキシソー ムへ輸送されているとは非常に考えにくい. DHAS の凝 集不活化はペルオキシソーム膜による仕切りが存在した ことによって起こった. また, Pmp47によって輸送され る化合物は，他のトランスポーターとの類似性から考え てATP などの低分子物質であることが予想される。こ の低分子物質をオルガネラ内で受け取るシャペロンのよ うなタンパク質性因子はペルオキシソームには存在しな いのだろうか?

pex5 変異株においても, DHAS は活性型で細胞質に 存在した (未発表データ). pex 5 変異株ではペルオキシ ソームは存在し, かつ Pmp47 はペルオキシソーム膜へ 輸送されているようである。もし，ペルオキシソーム内 タンパク質因子が PTS1 に依存して輸送されているの なら, pex5 変異株ではそのタンパク質因子は細胞質に DHAS と共存していることになり，DHAS 活性をもて るようになったと考えることはできないだろうか？ 本 当にすべてのタンパク質はペルオキシソームへ到達する 前にフォールディングされ, オルガネラ内にはシャペロ ン分子はないのであろうか？ そして Pmp47 の輸送す る低分子化合物とは何であろうか？ 現在, これらの問 題を解決すべく研究を進めている.

以上のようにDHAS のペルオキシソームへの輸送と Pmp47 の関係は, ペルオキシソームへのタンパク質輸 送に新たな問題を提起している.

$*$

現在, 酵母を用いたオルガネラ形成の分子細胞生物学 は大きく花を開いている.ここで紹介したペルオキシソ 一ム形成の分子機構の解明もその例外ではない. 予想以 上に多くの遺伝子がペルオキシソーム形成に関与してい る.ヒトのペルオキシン遺伝子は将来は遺伝子治療に利 用されることが期待され，もしそうなれば，10歳までに 命を終えてしまう多くの子供達の生命を救う素晴らしい 成果となるであろう。しかし遺伝子のクローニングでこ の物語は終わらない.ペルオキシンの生化学的機能を追 求するのが次のステップである. ペルオキシソームへの タンパク質輸送は他のオルガネラとは大きく異なってい
るようである．はたしてペルオキシソーム形成の分子機 構は我々に新しいパラダイムを与えてくれるのだろう か?

ここでは紹介できなかったが，メタノール資化性酵母 はペルオキシソーム形成のモデル生物として利用されて いるばかりでなく, 異種遺伝子発現系としても大変優れ たものである ${ }^{(17)}$. 筆者らは, メ夕ノール資化性酵母のぺ ルオキシソームヘタンパク質を詰め込んで, 効率的な夕 ンパク質生産を行なうことを目標とした研究を進めてい る.このために, 分子細胞生物学を応用分野へ取り込む ことも積極的に行ないたいし，逆に応用的な解釈で分子 細胞生物学を見直す視点があってもよいのではないだろ うか。

謝辞：共同研究者であるテキサス大学サウスウェスタン医学セン ターの Joel M. Goodman 教授には多くの研究材料ならびに貴重 な示唆をいただきました。また筆者が現在滞在しているカリフォ ルニア州立大学サンディエゴ校 S. Subramani 教授には図表の原 図ならびに最新の資料についてお教えいただきました。この場を 借りて両教授に深く感謝いたします.誌面上の制約で紹介できま せんでしたが, メタノール資化性酵母は故緒方浩一京都大学教授に より,またそのペルオキシソームは福井三郎京都大学名誉教授らに より発見され, 初めての哺乳類からのペルオキシン遺伝子は藤木幸 夫九州大学教授によりクローニングされていたことを特に記して おきたいと思います.日本におけるこのような独創的な研究なくし て, 筆者らの研究は不可能でした。 また, 本稿執筆の機会をお与え いただきました本誌元企画理事大山莞爾先生に感謝いたします.最 後になりましたが, 本研究を開始した当初ご指導いただきました谷 吉樹 奈良先端科学技術大学院大学教授, 現在ご指導いただいてお ります加藤暢夫京都大学教授ならびに共同研究者である由里本博 也氏ほか制御発酵学研究室の新旧メンバー全員に感謝いたします。

\section{文献}

1) S. Subramani : Nature Genet., 15, 331 (1997).

2) B. Distel, R. Erdmann, S.J. Gould, G. Blobel, D.I. Crane, J.M. Cregg, G. Dodt, Y. Fujiki, J.M. Goodman, W.W. Just, J.A.K.W. Kiel, W.-H. Kunau, P.B. Lazarow, G.P. Mannaerts, H.W. Moser, T. Osumi, R.A. Rachubinski, A. Roscher, S. Subramani, H. Tabak, T. Tsukamoto, D. Valle, I. van der Klei, P.P. van Veldhoben \& M. Veenhuis: J. Cell Biol., 135, 1 (1996).

3) S. Subramani : Annu. Rev. Cell Biol., 9, 445 (1993).

4) Y. Sakai, H. Matsuo, K.-Z. He, A. Saiganji, H. Yurimoto, K. Takabe, H. Saiki \& N. Kato : Biosci. Biotech. Biochem., 59, 869 (1995).

5) R.A. Rachubinski \& S. Subramani : Cell, 83, 525 (1995).

6) J.A. McNew \& J.M. Goodman : Trends Biochem. Sci., 21, 54 (1996).

7) S. Subramani : J. Biol. Chem., 271, 32483 (1996).

8) E.A.C. Wiemer, S.R. Terlecky, W.M. Nuttley \& S. Subramani : Cold Spring Harbor Symp. Quant. Biol., 60, 637 (1995).

9) S.J. Gould, J. Kalish, J.C. Morrell, J. Bjorkman, A.J. Urquhart \& D.I. Crane : J. Cell Biol., 135, 85 (1996).

10) Y. Elgersma, L. Kwast, A. Klein, T. Voorn-Brouwer, M. van den Berg, B. Metzig, T. America, H. Tabak \& B. Distel : J. Cell Biol., 135, 97 (1996).

11) R. Erdmann \& G. Blobel : J. Cell Biol., 135, 111 (1996). 
12) B. Huhse \& W. Kunau: Cold Spring Harbor Symp. Quant. Biol., 60, 657 (1995).

13) P. Rehling, M. Marzioch, F. Niesen, E. Wittke, M. Veenhuis \& W. Kunau : EMBO J., 15, 2901 (1996).

14) M. Albertini, P. Rehling, R. Erdmann, W. Girzalsky, J.A. K.W. Kiel, M. Veenhuis \& W. Kunau : Cell, 89, 83 (1997).

15) M. Komori, S.W. Rasmussen, J.A.K.W. Kiel, R.J.S. Baerends, J.M. Cregg, I.J. van der Klei \& M. Veenhuis : EMBO J., 16, 44 (1997).

16) J.M. Goodman, S.B. Trapp, H. Hwang \& M. Veenhuis : J. Cell Sci., 97, 193 (1990).

17）阪井康能：“遺伝子発現実験マニュアルー高発現システムによ る有用タンパク質の生産”，講談社サイエンティフィク，1994， p. 100.

18) Y. Sakai, P.A. Marshall, A. Saiganji, K. Takabe, H. Saiki, N. Kato \& J.M. Goodman : J. Bacteriol., 177, 6773 (1995).

19) R. Erdmann \& G. Blobel : J. Cell Biol., 128, 509 (1995).

20) P.A. Marshall, Y.I. Krimkevich, R.H. Lark, J. Dyer, M. Veenhuis \& J.M. Goodman : J. Cell Biol., 129, 345 (1995).

21) P.A. Marshall, J.M. Dyer, M.E. Quick \& J.M. Goodman : J. Cell Biol., 135, 123 (1996).

22) G.A. Eitzen, R.K. Szilard \& R.A. Rachubinski : J. Cell Biol., 137, 1265 (1997).

23) Y. Sakai, A. Saiganji, H. Yurimoto, K. Takabe, H. Saiki \& N. Kato: J. Cell Biol., 134, 37 (1996).

\section{ロ フィル}

荒井 修亮 (Nobuaki Arai) 昭和 32 年 1 月 30 日生 $<$ 略歴 $>$ 昭和 55 年京都大学 農学部水産学科卒業／同年農林水産省入 省 $/ 63$ 年科学技術庁勤務/平成 2 年農 林水産省勤務 $/ 4$ 年京都大学農学部助 手, 現在にいたる. 平成 9 年第 39 次南極 地域観測隊隊員<研究テーマと抱負 $>$ 海 洋生物の硬組織の解析. 海洋生物の行動 生態と海洋環境の解析を行なうための計 測方法 $<$ 趣味 $>$ テニス

井上 國世 (Kuniyo Inouye) Vol. 31, No. 9 , p. 577 参照

江島 大輔（Daisuke Ejima） 昭和 33 年 7 月 16 日生 $<$ 略歴 $>1983$ 年東京大学 農学部水産学科卒業後, 味の素(株) 中央 研究所勤務, 現在にいたるく研究テーマ と抱負 >遺伝子組換え技術を用いたタン パク質の製造技術開発 $<$ 趣味 $>$ 動物園め ぐり

小川 宏蔵（Kozo Ogawa）昭和 14 年 7 月 31 日生 $<$ 略歴 $>$ 昭和 40 年大阪府立 大学大学院農学研究科修士課程修了／同 年大阪府立放射線中央研究所勤務 /平成 2 年大阪府立大学附属研究所助教授 $/ 7$ 年同大学先端科学研究所教授, 現在にい たる。この間，昭和 $50 \sim 51$ 年カナダ・ モントリオール大学化学部博士研究員 (R.H. Marchessault 研). 昭和 49 年農
博 $($ 大阪府立大学 $)<$ 研究テーマと抱負 $>$ 組織状生体高分子の構造と機能. 合成高 分子の優れた機能をもつ生体高分子ある いは(生分解性を損わない)誘導体を見つ け，その構造と機能の相関を明らかにす ること<趣味 $>$ 音楽鑑賞

小幡 斎 (Hitoshi Obata) 昭和 14 年 5 月 8 日生 $<$ 略歴 $>$ 昭和 38 年関西大 学工学部化学工学科卒業 $/ 41$ 年同工学 部助手 $/ 52$ 年同専任講師 $/ 56$ 年同助教 授 $/ 63$ 年同教授, 現在にいたる。この 間, 昭和 56 年および 59 年カナダ・アル バー夕州立研究所留学<研究テーマと抱 負 >微生物由来の水を凍りやすくする夕 ンパク質と水を凍りにくくするタンパク 質の構造と機能, その応用 $<$ 趣味 $>$ 化石 収集，ドライブ

越智 幸三（Kozo Ochi） Vol. 31，No. 3 , p. 162 参照

越智 宏倫 (Hirotomo Ochi) 昭和 9 年 7 月 1 日生 $<$ 略歴 $>$ 昭和 34 年大阪府立 大学農学部農芸化学科卒業/39 年日研 フード (株)代表取締役就任 $/ 60$ 年日本 老化制御研究所所長兼任, 現在にいたる. この間, 昭和 63 年米国ホノルル大学よ り Ph.D. 取得, 平成元年農博 (東北大 学) <研究テーマと抱負 >老化制御に関 する研究および商品開発＜趣味 $>$ 読書,
園芸

川上秀史 (Hideshi Kawakami) 昭 和 34 年 7 月 11 日生 $<$ 略歴 $>$ 昭和 59 年 広島大学医学部医学科卒業 $/ 63$ 年京都 大学大学院医学研究科単位取得後退学 / 平成元年国立療養所宇多野病院神経内科 レジデント $/ 5$ 年広島大学医学部医学科 内科学第三講座助手, 現在にいたるく研 究テーマと抱負 $>$ 神経疾患の分子生物学 的研究 (グルタミン酸トランスポーター, ドーパミントランスポーター, triplet repeats disease など)

河原 秀久 (Hidehisa Kawahara) 昭 和 37 年 6 月 15 日生 $<$ 略歴 $>$ 昭和 61 年 岡山大学農学部農芸化学科卒業/平成 3 年同大学大学院自然科学研究科博士課程 修了/同年関西大学工学部助手 $/ 6$ 年同 専任講師 $/ 9$ 年同助教授, 現在にいた る<研究テーマと抱負 $>$ 様々な環境に生 育している細菌の新機能開発とその応用 研究 $<$ 趣味 $>$ スポーツ観戦

佐竹 真幸（Masayuki Satake） 昭和 39 年 4 月 17 日生 $<$ 略歴>平成元年東北 大学農学部食糧化学科卒業 $/ 6$ 年同大学 大学院農学研究科博士課程修了/同年同 農学部助手, 現在にいたる<研究テーマ と抱負 $>$ 海洋天然物化学 $<$ 趣味 $>$ スポー ツ，読書 